This item was submitted to Loughborough's Research Repository by the author.

Items in Figshare are protected by copyright, with all rights reserved, unless otherwise indicated.

\title{
Banking efficiency and stock market performance: an analysis of listed Indonesian banks
}

PLEASE CITE THE PUBLISHED VERSION

PUBLISHER

(c) Loughborough University

VERSION

VoR (Version of Record)

LICENCE

CC BY-NC-ND 4.0

\section{REPOSITORY RECORD}

Hadad, Muliaman D., Maximilian J.B. Hall, Karligash Kenjegalieva, Wimboh Santoso, Ricky Satria, and Richard Simper. 2019. "Banking Efficiency and Stock Market Performance: An Analysis of Listed Indonesian Banks". figshare. https://hdl.handle.net/2134/4201. 
This item was submitted to Loughborough's Institutional Repository (https://dspace.lboro.ac.uk/) by the author and is made available under the following Creative Commons Licence conditions.

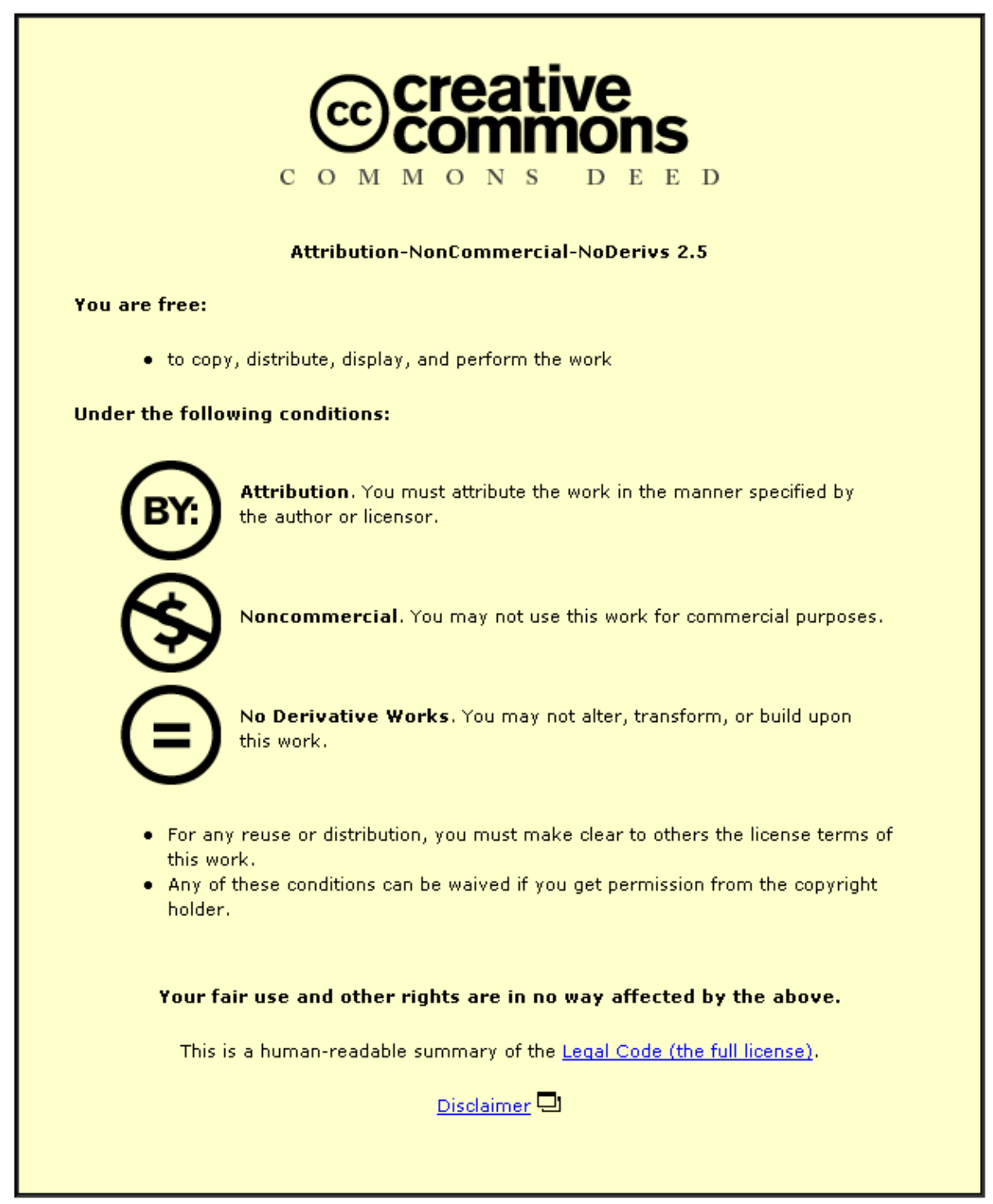

For the full text of this licence, please go to: http://creativecommons.org/licenses/by-nc-nd/2.5/ 
ISSN 1750-4171

\title{
DEPARTMENT OF ECONOMICS
}

\author{
DISCUSSION PAPER SERIES
}

\author{
Banking Efficiency and Stock Market \\ Performance: \\ An Analysis of Listed Indonesian Banks
}

\section{Muliaman D. Hadad, Maximilian J. B. Hall, Karligash Kenjegalieva, Wimboh Santoso, Ricky Satria and Richard Simper}

\section{WP 2008 - 07}




\title{
Banking Efficiency and Stock Market Performance: An Analysis of Listed Indonesian Banks
}

\author{
Muliaman D. Hadad ${ }^{* 1}$, Maximilian J. B. Hall ${ }^{2}$, Karligash A. Kenjegalieva ${ }^{2}$, Wimboh \\ Santoso $^{* 1}$, Ricky Satria ${ }^{* 1}$ and Richard Simper ${ }^{1,3}$ \\ ${ }^{1}$ Bank Indonesia, J1. MH. Thamrin 2, Jakarta, 10350 Indonesia. \\ ${ }^{2}$ Department of Economics, Loughborough University, Ashby Road, Loughborough, \\ England, LE11 3TU.
}

\begin{abstract}
This paper examines the monthly efficiency and productivity of listed Indonesian banks and their market performance through the prism of two modelling techniques, efficiency and super-efficiency, over the period January 2006 to July 2007. Within this research strategy we employ Tone's (2001) non-parametric, Slacks-Based Model (SBM) and Tone's (2002) super-efficiency SBM combining them with recent bootstrapping techniques, namely the non-parametric truncated regression analysis suggested by Simar and Wilson (2007). In the case of the SBM efficiency scores, the Simar and Wilson methodology was adapted to two truncations, whereas in the super-efficiency framework the original technique was utilised. As suggested by neo-classical theory, we find that the stock market values banks in accordance with their performance. Moreover, it is found that the JCI index of the Indonesian Stock Exchange is positively related to bank efficiency. Another interesting finding is that the coefficient for the share of foreign ownership is negative and statistically significant in the super-efficiency modelling. This suggests that Indonesian banks with foreign ownership tend to be less efficient than their domestic counterparts. Finally, Malmquist productivity results suggest that, over the study's horizon, the sample banks displayed volatile productivity patterns in their profitgenerating operations.
\end{abstract}

JEL Classification: C23; C52; G21

Keywords: Indonesian Banking; Emerging Markets; Productivity; Efficiency 


\section{INTRODUCTION}

Since the seminal paper by Benston (1965), who found that both unit and branching New England banks experienced economies of scale in the majority of their product business, efficiency analysis in banking has grown in complexity and has given greater insight into potential problems that banks and financial systems can face. However, within the literature, the majority of early papers (pre-1990s), considered changes in bank scale economies primarily based on North American financial markets (see Murray and White, 1983, for an early Canadian example). This was due to the widely available data sets arising from US banks filling in a Call Report on form FFIEC032 quarterly, or questionnaires concerning employee costs, etc., that were sent out to banks, for example, by the authors in the latter paper. Given these comprehensive data sets, researchers then had the ability to determine cost or profit efficiencies for various banking types (see Fan and Shaffer, 2004). Hence, the analysis of bank efficiency is well developed in North American cases, while problems with data collection and specifically the inputs/outputs/prices variables needed in efficiency modelling have led to under-researched systems elsewhere in the World.

Indeed, despite the development of S.E. Asian banking systems, there is a dearth of studies that estimate scale and/or X-efficiencies in banks in this region compared with the number of North American studies. Some early papers that do exist include: Pulley and Braunstein (1992), which was expanded by McKillop et al. (1996) for Japanese banks; Kwan (2002), for Hong Kong banks; Gilbert and Wilson (1998), for Korean banks; Dogan and Fausten (2003), for Malaysian banks; Chu and Lim (1998), for Singaporean banks; Unite and Sullivan (2003), for Philippine banks; and Leightner and Knox Lovell (1998), for Thai banks. As various techniques in both non-parametric and parametric approaches have advanced, these early examples have been updated by, for example: Drake et al. (2006) expanding the findings of Kwan (2002), by incorporating environmental factors in the efficiency scores for Hong Kong banks; and, by Drake et al. (2008) expanding McKillop et al. (1996) by considering the correlation of efficiency scores across three different modelling methodologies for Japanese banks. Therefore, given the growing importance of S.E. Asian banking systems, it is both timely and 
warranted that these newer markets, such as Indonesian banking, should now be considered.

However, to the authors' knowledge, there has been few (if any) published papers focusing on Indonesian banking markets, although some cross-country comparative S.E. Asian papers do exist; see, for example, Williams and Nguyen (2005). Comparative analysis of Indonesian banks is warranted for many reasons, yet the latter paper assumes that a common frontier can be modelled over a number of S.E. Asian countries, implying that their business techniques and environments are similar. If we just consider population statistics this assumption is unlikely to hold true: Indonesia, 231 million; Hong Kong, 7 million; Japan, 127 million; Singapore, 5 million; and Thailand, 63 million. Further, since the Asian financial crisis in 1997, Asian countries have been changing their once restrictive banking practices at different speeds and for different motives (in Indonesia's case, in part due to the removal of the Soeharto regime and all that that entailed; see Hill and Shiraishi, 2007). Hence, by definition, they are unlikely to compete in the same input and output markets and therefore estimating a common frontier without taking into account external factors could lead to misleading results; see Drake et al (2006) and Kenjegalieva et al (2007).

This study, therefore, represents one of the first to examine the efficiency of listed Indonesian banks, utilising monthly supervisory data collected by Bank Indonesia during 2006 and 2007. In addition, we utilise a recent advancement in non-parametric modelling by estimating monthly efficiencies using a technique proposed by Tone (2001 and 2002) which takes into account the radial-slacks when estimating Data Envelopment Scores. Further, this is the first study, to the authors' knowledge, that then takes these monthly efficiency scores and, using a recent modelling program proposed by Simar and Wilson (2007), regresses these scores on stock prices, thereby testing the efficient markets hypothesis for the Indonesian stock exchange.

The paper is structured as follows. A brief review of the Indonesian banking industry and performance indicators are provided in Section 2. Section 3 explains the modelling methodology adopted and discusses the data utilised. Section 4 outlines the empirical results and Section 5 summarises and concludes. 


\section{THE INDONESIAN BANKING INDUSTRY: A BRIEF REVIEW}

As demonstrated in Table 1, at the end of June 2007 there were 130 banks operating in Indonesia with a combined balance sheet of over IDR 1,770 trillion (US\$ 190 billion). This comprised 5 state-owned banks, 35 foreign exchange private national banks, 36 non-foreign exchange private national banks, 26 regional government-owned banks, 17 joint venture banks and 11 foreign banks. This total compares with a figure of 222 banks in existence at end-December 1997, the shrinkage being largely due to postcrisis liquidation and suspension, engineered by the Indonesian Bank Restructuring Agency (IBRA) under agreement with the IMF (Jao, 2001, Ch.2), and mergers.

\section{INSERT TABLE 1}

Some indicators of industry performance are presented in Table 2. Positive features are the capital adequacy ratio of $21 \%$ (up from $13 \%$ at end-December 2000), the gross NPL ratio of $6.4 \%$ (down from $19 \%$ at end-December 2000) and the return on assets ratio of $2.8 \%$ (up from $0.9 \%$ at end-December 2000). Continuing excess liquidity in the banking system, however, is reflected in the relatively-low $67 \%$ loans to deposits ratio, although this has recently improved (46\% at end-December 2000).

\section{INSERT TABLE 2}

\section{DATA AND MODELLING METHODOLOGY}

\subsection{Estimation of Efficiency}

Data Envelopment Analysis (DEA) originated from Farrell's (1957) seminal work and was later elaborated on by Charnes et al. (1978), Banker et al. (1984) and Färe et al. (1985). The objective of DEA is to construct a relative efficiency frontier through the envelopment of the Decision Making Units (DMUs) where the 'best practice' DMUs 
form the frontier. In this study, we utilize a DEA model which takes into account input and output slacks, the so-called Slacks-Based Model (SBM), which was introduced by Tone (2001) and ensures that, in non-parametric modelling, the slacks are taken into account in the efficiency scores. Or, as Fried et al. (1999) argued, in the 'standard' DEA models based on the Banker et al. (1984) specification "the solution to the DEA problem yields the Farrell radial measure of technical efficiency plus additional non-radial input savings (slacks) and output expansions (surpluses). In typical DEA studies, slacks and surpluses are neglected at worst and relegated to the background at best" (page 250). Indeed, in the analysis of public sector Decision Making Units (DMUs), for which DEA was originally proposed by Farrell, the idea of slacks was not a problem unlike it is when DEA is employed to measure cost efficiencies in a 'competitive market' setting. That is, in a 'competitive market' setting, output and input slacks are essentially associated with the violation of 'neo classical' assumptions. For example, in an input-oriented approach, the input slacks would be associated with the assumption of strong or free disposability of inputs which permits zero marginal productivity of inputs and hence extensions of the relevant isoquants to form horizontal or vertical facets. In such cases, units which are deemed to be radial- or Farrell- efficient (in the sense that no further proportional reductions in inputs is possible without sacrificing output), may nevertheless be able to implement further additional reductions in some inputs. Such additional potential input reductions are typically referred to as non-radial input slacks, in contrast to the radial slacks associated with DEA or Farrell inefficiency, that is, radial deviations from the efficient frontier. In addition, to rank the best performers among the listed Indonesian banks, we employ the super-efficiency SBM model proposed by Tone (2002).

In our modelling, we assume there are $n$ listed banks (DMUs) operating in the banking industry which convert inputs $X(m \times n)$ into outputs $\mathrm{Y}(s \times n)$ using common technology $T$ which can be characterised by the technology set $\hat{T}$ estimated using DEA:

$$
\hat{T}=\left\{(x, y) \in \mid y_{o} \leq Y \lambda, x_{o} \geq X \lambda, \sum \lambda=1, \lambda \geq 0\right\}
$$


where $x_{o}$ and $y_{o}$ represent observed inputs and outputs of a particular DMU and $\lambda$ is the intensity variable. $\hat{T}$ is a consistent estimator of the unobserved true technology set under variable returns to scale. This means that, given our aim of analyzing the impact of market driven factors on the SBM efficiency scores, the assumptions outlined in Simar and Wilson (2007) hold, hence allowing for the provision of consistent estimators of the parameters in a fully specified, semi-parametric Data Generating Process (DGP).

Given these conditions, the individual input-oriented efficiency for each DMU is computed relative to the estimated frontier by solving the following SBM linear programming problem:

$$
\begin{array}{ll}
\min & \hat{\rho}(x, y \mid T(x))=1-\frac{1}{m} \sum_{k=1}^{m} s_{k}^{-} / x_{k o} \\
\text { subject to } & x_{o}=X \lambda+s^{-}, \\
& y_{o}=Y \lambda-s^{+}, \\
& \sum \lambda=1, \\
& \lambda \geq 0, \quad s^{-} \geq 0, \quad s^{+} \geq 0,
\end{array}
$$

where $s^{-}$is output shortfall, $s^{+}$is input excess, and an optimal solution of program (2) is given by $\left(\hat{\rho}, \hat{\lambda}, \hat{s}^{-}, \hat{s}^{+}\right)$.

For banks with a SBM efficiency score $\hat{\rho}\left(x_{o}, y_{o} \mid T(x)\right)=1$, we additionally estimate the super-efficiency performance measure $\hat{\delta}\left(x_{0}, y_{0} \mid T_{*}(x)\right)$ using the following input-oriented Super-SBM model:

$$
\begin{array}{ll}
\min & \hat{\delta}\left(x_{0}, y_{0} \mid T_{*}(x)\right)=\frac{1}{m} \sum_{k=1}^{m} \bar{x}_{k} / x_{k 0} \\
\text { subject to } & \bar{x} \geq \sum_{j=1, \neq 0}^{n} \lambda_{j} x_{j}, \\
\bar{y} \geq \sum_{j=1, \neq 0}^{n} \lambda_{j} y_{j}, \\
\sum \lambda=1,
\end{array}
$$


In the super-efficiency set of results, the inefficient banks (that is, $\hat{\delta}_{j}=\hat{\rho}_{j}<1$ if bank $j$ is inefficient) have their efficiency scores estimated by (2), and for efficient banks $\left(\hat{\delta}_{j}=\hat{\delta}_{j} \geq 1\right)$ they are estimated by (3).

In the second stage of this analysis, the efficiency measures $\hat{\rho}_{j}$ estimated using program (2) are regressed on market-specific factors. That is, if $z_{j}$ is a vector of bankspecific factors of the $j$-th DMU and $\beta$ is a vector of parameters associated with each factor to be estimated, then

$$
0 \leq \rho_{j}=\psi\left(z_{j}, \beta\right)+\varepsilon_{j} \leq 1
$$

In equation (4), $\rho_{j}$ is the true efficiency measure of the $j$-th bank ( $\hat{\rho}_{j}$, calculated using program (2), is considered as an estimate for $\left.\rho_{j}\right), \psi$ is a smooth continuous function, $\beta$ is a vector of parameters, and $\varepsilon_{j}$ is a truncated random variable $N\left(0, \sigma_{i}^{2}\right)$ truncated at $\left(-\psi\left(z_{j}, \eta\right)\right)$ and $\left(1-\psi\left(z_{j}, \eta\right)\right)$.

The efficiencies calculated utilizing program (2), however, are biased in comparison with the true efficiencies, $\rho_{j}$. Hence, we correct the efficiency scores $\hat{\rho}_{j}$ for the biased term which arises as a consequence of the market factors affecting the performance of Indonesian banks listed on the stock market using Algorithm 2 of Simar and Wilson (2007) with two truncation points. That is, we estimate the efficiency measure $\hat{\rho}_{j}$ utilizing program (2), then use the truncated regression to regress $\hat{\rho}_{j}$ on $z_{j}$ in equation (4) for $l<n$ observations where $0<\hat{\rho}_{j}<1$ using maximum likelihood estimation to obtain an estimate $\hat{\beta}$ of $\beta$ and an estimate $\hat{\sigma}_{\varepsilon}$ of $\sigma_{\varepsilon}{ }^{1}$. Then we estimate the

\footnotetext{
1 The log likelihood is given by the following function, where $a$ and $b$ are respectively left and right constant truncations:
} 
$L_{1}=100$ bootstrap estimates for each $\hat{\rho}_{j}$ to provide $n$ sets of bootstrap estimates, $B_{j}=\left\{\hat{\rho}_{j b}^{*}\right\}_{b=1}^{L_{1}}$. For each $j=1, \ldots, n$, we draw $\varepsilon_{j}$ from the distribution $N\left(0, \hat{\sigma}_{\varepsilon}^{2}\right)$ with left truncation at $\left(-\psi\left(z_{j}, \eta\right)\right)$ and right truncation at $\left(1-\psi\left(z_{j}, \eta\right)\right)$ and compute $\hat{\rho}_{j}^{*}=z_{j} \hat{\beta}+\varepsilon_{j}$. To obtain draws from a normal distribution with left and right truncations, the procedure, as described in Simar and Wilson (2007) [sub-appendix A.2 (p.60)], was used with a left truncation at constant $a$ and a right truncation at constant $b$. In addition, we generate $v$ from a uniform distribution $(0,1)$ and let $a^{\prime}=a / \sigma$ and $b^{\prime}=b / \sigma$, and set $v^{\prime}=\Phi\left(a^{\prime}\right)+\left[\Phi\left(b^{\prime}\right)-\Phi\left(a^{\prime}\right)\right] v$. The normal deviate with right and left truncation is equal to $u=\sigma \Phi^{-1}\left(v^{\prime}\right)$.

With respect to the elimination of the bias, the inputs $x_{j}$ are modified as $x_{j}^{*}=x_{j} \hat{\rho}_{j} / \rho_{j}^{*}$ for all $j=1, \ldots, n$, while keeping the output measures $y_{j}$ unchanged, $y_{j}^{*}=y_{j}$. Given these changes, we re-estimate $\hat{\rho}_{j}^{*}$ for all $j=1, \ldots, n$, by solving program (2) and replacing $X$ and $Y$ with $X^{*}=\left[x_{1}^{*} \ldots x_{n}^{*}, x_{j}\right]$ and $Y^{*}=\left[y_{1}^{*} \ldots y_{n}^{*}, y_{j}\right]$ respectively. It should be noted that the frontier for bank $j$ is constructed with respect to the $X^{*}$ and $Y^{*}$, which contain the original inputs $x_{j}$ and outputs $y_{j}$ of bank $j$. This is due to the referenceset dependence property of the SBM efficiency measure $\hat{\rho}_{j}$, that is, it "is not affected by values attributed to other DMUs not in the reference set" (Tone, 2001, p. 501).

Finally, we compute the bias-corrected estimator $\hat{\hat{\rho}}_{j}$ for each $j=1, \ldots, n$, such that $\hat{\hat{\rho}}_{j}=\hat{\rho}_{j}+\operatorname{BIAS}\left(\hat{\rho}_{j}\right)$. Again, it is interesting to note that, in an input-orientated specification, the bias is added to the estimated efficiency measures ${ }^{2}$. This follows nicely the procedure utilised in cost functions in Stochastic Frontier Analysis (SFA).

$$
L=-\frac{n}{2} \log \left(2 \pi \sigma_{\varepsilon}^{2}\right)-\frac{1}{2 \sigma_{\varepsilon}^{2}} \sum_{j=1}^{n}\left(\rho_{j}-z_{j} \eta\right)^{2}-\sum_{i=1}^{n} \log \left\{\Phi\left(\frac{b-z_{j} \eta}{\sigma_{\varepsilon}}\right)-\Phi\left(\frac{a-z_{j} \eta}{\sigma_{\varepsilon}}\right)\right\} .
$$

\footnotetext{
${ }^{2}$ The bias term of input-oriented efficiency measures estimated by the Charnes et al (1978) and Banker et al (1984) DEA models is negative. Note, however, that the bias term estimated for SBM efficiency measures does not have a consistent sign.
} 
The second bootstrap procedure of Algorithm 2 of Simar and Wilson (2007) is similar to Algorithm 1. The only difference is that, in Algorithm $1, \hat{\rho}_{j}$ is used as a dependent variable of the truncated regression whereas, in Algorithm 2, the biascorrected estimate, $\hat{\hat{\rho}}_{j}$, is used. This second bootstrapping technique ensures that the problem of serial correlation of the efficiency measures is avoided. The following steps are performed in the second bootstrap procedure of Algorithm 2:

1. Estimate the truncated regression of $\hat{\hat{\rho}}_{j}$ on $z_{j}$ in (4) for $m=n$ observations using maximum likelihood estimation to obtain estimates for $\hat{\beta}$ and $\hat{\sigma}_{\varepsilon}$.

2. Compute a set of $L$ bootstrap estimates (we set $L$ to equal 1000 replications) for $\beta$ and $\sigma_{\varepsilon}, A=\left\{\left(\hat{\beta}^{*}, \hat{\sigma}_{\varepsilon}^{*}\right)_{b}\right\}_{b=1}^{L}$, in the following way: for each $j=1, \ldots, m$, draw $\varepsilon_{j}$ from the normal distribution $N\left(0, \hat{\sigma}_{\varepsilon}^{2}\right)$ with left truncation at $\left(-\psi\left(z_{j}, \eta\right)\right)$ and right truncation at $\left(1-\psi\left(z_{j}, \eta\right)\right)$ and compute $\hat{\hat{\rho}}_{j}^{*}=z_{j} \hat{\beta}+\varepsilon_{j} ;$ then estimate the truncated regression of $\hat{\hat{\rho}}_{j}^{*}$ on $z_{j}$ using maximum likelihood methods to obtain the parameter estimates $\left(\hat{\beta}^{*}, \hat{\sigma}_{\varepsilon}^{*}\right)$. Once the set of $L$ bootstrap parameter estimates for $\beta$ and $\sigma_{\varepsilon}$ have been obtained, the percentile bootstrap confidence intervals can then be constructed.

In addition, we analysed the determinants of the super-efficiency of Indonesian banks using Algorithms 1 and 2. Since super-efficiency scores $\hat{\delta}_{j}$ have only one boundary at zero we employ the original methodology of Simar and Wilson (2007), changing the value of the left truncation point. In other words, the following regression is estimated:

$$
0 \leq \delta_{j}=\psi\left(z_{j}, \beta\right)+\varepsilon_{j}
$$

where $\delta_{j}$ is the true efficiency measure of the $j$-th bank ( $\hat{\delta}_{j}$, calculated using programs (2) and (3), is considered as an estimate for $\delta_{j}$ ), $\psi$ is a smooth continuous function, $\beta$ is a vector of parameters, and $\varepsilon_{j}$ is a truncated random variable $N\left(0, \sigma_{i}^{2}\right)$ truncated at 
$\left(\psi\left(z_{j}, \eta\right)\right)$. The reference set dependency is dealt with in a similar manner to the efficiency estimates $\hat{\rho}_{j}$.

\subsection{Productivity Analysis in the SBM Context}

The measurement and analysis of productivity growth have attracted increased interest among researchers studying bank performance. A Malmquist index of productivity change, initially defined by Caves, Christensen and Diewert (1982) and extended by Färe et al. (1992) by merging it with Farrell's (1957) efficiency measurement, has become increasingly popular. However, as discussed earlier, if the technology is estimated using the DEA models suggested by Charnes et al. (1978) or Banker et al. (1984), input and output slacks are ignored. Hence, for the estimation of the Malmquist productivity index, similar to the study of Liu and Wang (2008), we utilise SBM and super-SBM models introduced by Tone (2001) and Tone (2002) respectively. However, unlike Liu and Wang (2008), we employ an input-oriented modification of the models.

Accordingly, the individual input-oriented efficiency for each DMU in period $t$ is computed relative to the estimated frontier of period $t$ by solving the SBM linear programming problems (2) and (3) above. The performance measures for the DMU $o$ operated in time $\mathrm{t}+1, \hat{\rho}\left(x_{o}^{t+1}, y_{o}^{t+1} \mid T^{t+1}(x)\right)$ and $\hat{\delta}\left(x_{0}^{t+1}, y_{0}^{t+1} \mid T_{*}^{t+1}(x)\right)$, can also be obtained using models (2) and (3) by changing $t$ to $t+1$.

The Malmquist productivity index of the $\mathrm{DMU}_{o}$ between periods $t$ and $t+l$ is estimated as follows, in line with Färe et al. (1992):

$$
M_{o}^{t, t+1}=\left[\frac{\hat{\rho}\left(x_{o}^{t+1}, y_{o}^{t+1} \mid T^{t}(x)\right)}{\hat{\rho}\left(x_{o}^{t}, y_{o}^{t} \mid T^{t}(x)\right)} \frac{\hat{\rho}\left(x_{o}^{t+1}, y_{o}^{t+1} \mid T^{t+1}(x)\right)}{\hat{\rho}\left(x_{o}^{t}, y_{o}^{t} \mid T^{t+1}(x)\right)}\right]^{1 / 2} .
$$

If the productivity measure $M_{o}^{t, t+1}>1$, then this implies a productivity gain for $D M U_{o}$ between period $\mathrm{t}$ and $\mathrm{t}+1$, and, contrariwise, a $M_{o}^{t, t+1}<1$ indicates a productivity loss. 
$M_{o}^{t, t+1}=1$ implies that $D M U_{o}$ has no change in its productivity. The productivity measure $M_{o}^{t, t+1}$ can also be decomposed into two indices which capture technical efficiency change $\left(T E C_{o}\right)$ between periods $t$ and $t+1$, and the technological (frontier) change $\left(F S_{o}\right)$, (i.e., the shift of the technology between two periods), as follows:

$$
M_{o}^{t, t+1}=T E C_{o} \times F S_{o}=\frac{\hat{\rho}\left(x_{o}^{t+1}, y_{o}^{t+1} \mid T^{t+1}(x)\right)}{\hat{\rho}\left(x_{o}^{t}, y_{o}^{t} \mid T^{t}(x)\right)} \times\left[\frac{\hat{\rho}\left(x_{o}^{t+1}, y_{o}^{t+1} \mid T^{t}(x)\right)}{\hat{\rho}\left(x_{o}^{t+1}, y_{o}^{t+1} \mid T^{t+1}(x)\right)} \frac{\hat{\rho}\left(x_{o}^{t}, y_{o}^{t} \mid T^{t}(x)\right)}{\hat{\rho}\left(x_{o}^{t}, y_{o}^{t} \mid T^{t+1}(x)\right)}\right]^{1 / 2}
$$

$T E C_{o}$ measures the efficiency improvement of $D M U_{o}$, which, in the case where $T E C_{o}=1$, shows that the bank is still in the same position relative to the efficient boundary. When $T E C_{o}>1$, the bank has moved closer to the frontier, whereas for $T E C_{o}<1$ the bank has moved away from the frontier during the two periods. With regard to $F S_{o}$, an $F S_{o}<1$ indicates a negative shift of the frontier (or regression), $F S_{o}>1$ a positive shift (progress) and $F S_{o}=1$ implies no shift in the technological frontier.

\subsection{Data and Inputs/Outputs Used}

As stated in the introduction, this is the first paper to utilise monthly supervisory data from Bank Indonesia and covers the period from 2006 to 2007. All (24) listed banks feature in the sample.

In relation to our choice of inputs and outputs, recently banking studies have been criticised for neglecting the profit side of banking operations. It has been shown, for example, that banks exhibiting the highest inefficiencies and highest costs may be able to generate greater profits than more cost-efficient banks (Berger and Mester, 1997). A further criticism of many previous studies of banking efficiency is that they have not adequately taken account of technical change and variations in efficiency through time. Hence, variations in banking efficiency / performance can come from many sources, and it is imperative that all possible sources of variation are examined and to explain the often 
pronounced differences in profitability across different banks in a sample. Our choice of inputs and outputs and modelling methodology addresses both issues.

The outputs used in this study embrace: Y1: Net interest Income; Y2: Net Trading Income [(income from forex/derivative transactions - loss from forex/derivative transactions) + (securities appreciation - securities depreciation)]; and Y3: Net offbalance sheet income (income from dividends/commissions/fees and provisions expenses deriving from dividends/commissions/fees and provisions). The inputs follow previous profit-based studies [for example, Drake et al (2006)], where: X1 is total employee expenses (total salaries and wages + education and training costs); X2 is total non-employee expenses (research and development costs + rent + advertising, maintenance and repair costs + goods and services costs + other non-employee costs); and $\mathrm{X} 3$ is provision for earning assets losses.

With respect to the last-mentioned input variable (i.e., provisions), it has long been argued in the literature that the incorporation of risk/loan quality is vitally important in studies of banking efficiency. Akhigbe and McNulty (2003), for example, utilising a profit function approach, include equity capital "to control, in a very rough fashion, for the potential increased cost of funds due to financial risk" (page. 312). Altunbas et al. (2000) and Drake and Hall (2003) also find that failure to adequately account for risk can have a significant impact on relative efficiency scores. In contrast to Akhigbe and McNulty (2003), however, Laevan and Majnoni (2003) argue that risk should be incorporated into efficiency studies via the inclusion of loan loss provisions. That is, "following the general consensus among risk agent analysts and practitioners, economic capital should be tailored to cope with unexpected losses, and loan loss reserves should instead buffer the expected component of the loss distribution. Consistent with this interpretation, loan loss provisions required to build up loan loss reserves should be considered and treated as a cost; a cost that will be faced with certainty over time but that is uncertain as to when it will materialise" (page 181). We agree with this view and hence also incorporate provisions as an input/cost in the DEA relative efficiency analysis of Indonesian banks. 


\section{RESULTS}

\subsection{First Stage: SBM Efficiency and Super-Efficiency Estimates}

The SBM efficiency and super-efficiency scores for Indonesian banks listed on the Indonesian Stock Exchange (IDX) are presented in Table 3. According to the SBM efficiency results, the three most efficient banks over the studied period are "idsb", "iihp" and "iimb". 3 Under the super-efficiency framework, the same banks, along with the "liir" bank, are found to have average efficiency levels above unity. Interestingly, with the exception of the "iihp" bank (which is partially foreign in ownership), these banks are domestically-owned.

The two least efficient banks, with average efficiency levels less than 50\%, are the domestically owned "ddpi" and "iimr" banks. Moreover, the latter is found to be the most inefficient bank among the listed banks over the analysed period, with efficiency levels ranging between $28 \%$ and $44 \%$. Other listed banks which have not achieved their frontiers in the analysed time span are the domestic bank "ddhb" and the partially foreign-owned "iibi", "iihb" and "iihi" banks. These banks are at best only 78\% efficient. Although the domestic banks "ihhr", "ipqa", "irrb" and the partially foreignowned bank "iqma" are found to consistently use their resources inefficiently, they do appear to operate sometimes close to the best practice frontier with their highest efficiency measures ranging between $84 \%$ and $90 \%$. The remaining banks have relatively-high efficiency levels and are considered further in the super-efficiency analysis.

\section{INSERT TABLE 3}

Although the partially foreign-owned bank "idqa" operated with no input slacks (i.e.,efficiently, according to the input-oriented SBM) in Sept 2006 and in May and July 2007, its efficiency level showed considerable fluctuation over the analysed period. For example, it was only $11 \%$ in May 2006, which is the lowest efficiency estimate among

\footnotetext{
${ }^{3}$ Codes are used to preserve the confidentiality of the data.
} 
the considered banks during the sample period, and its highest efficiency was $126 \%$ - the sixth highest super-efficiency score of the sample.

\subsection{Second Stage: Determinants of Efficiency}

Tables 4 and 5 present the results of the truncated regression analysis for the SBM efficiency measures utilising Algorithms 1 and 2 respectively of the Simar and Wilson (2007) technique with left and right truncation points. The analysis of the factors affecting the SBM super-efficiency scores using the aforementioned algorithms with left truncation is shown in Tables 6 and 7; whilst the results of the first part of the bootstrapping procedure of Algorithm 2, for both the SBM efficiency and SBM superefficiency models, are reported in the Appendix. To assess the relationship between the performance of the banks and their market values, in the model specification we include banks' share prices. In addition, to capture the effect of the overall condition of the Indonesian stock market, the JCI index is included. Nearly half of the listed banks are partially-owned by foreign investors, with ownership shares ranging from $1.6 \%$ to $79.4 \%$. This factor is also incorporated in the study. Finally, in order to assess the dynamics of the changes in the banks' performance, time and time squared (Time_sq) variables are also included.

\section{INSERT TABLES 4 AND 5}

In all the aforementioned models, share prices are positive and significant at the $1 \%$ level of significance. This is evidence confirming neo-classical theory which states that the stock market values banks in accordance with their performance. A similar finding is reported by Beccalli et al. (2006), who investigate the relationship between the operating efficiency of European banks and their stock market performance. Moreover, the positive and significant coefficient for the JCI index implies that the efficiencies of the banking firms are also positively related to the overall performance of the market. This is an expected result given that banks form an integral part of the economy. The 
correlation between the stock market index's performance and that of banking efficiency can also be explained through the intimate link between the bank and the firms that make up its clientele. Strong performances by the latter would automatically result in improved performance of the former through increased demand for banking services.

\section{INSERT TABLES 6 and 7}

Another interesting finding is that the coefficient for the variable capturing the share of foreign ownership ("F.O.S") is negative and statistically significant in the superefficiency model. This suggests that the performance of Indonesian banks with foreign ownership tends to lag behind that of their domestic counterparts. Our results are thus different from those pertaining to many studies of banking industries in emerging, transition and developed countries (see Bonin et al. (2005), Fries and Taci (2005), Havrylchyk, (2006), Sathye (2003), Sturm and Williams (2004) and Fukuyama et al. (1999)). However, they are in line with those of Hasan and Marton (2003), who find evidence in favour of inferior operating performance of foreign banks vis-à-vis their domestic counterparts in their studies of transition banking. In addition, more recently Lensink et al. (2008) provide evidence of a negative effect of foreign ownership on bank efficiency in their analysis of over 2000 banks in 105 countries. While these authors cite conditions of the banking system and of the economy as reasons for the underperformance of foreign banks, in our study it may be the sub-prime market distress that is responsible, given the relative stability in the Indonesian banking system and wider economy during 2006/07 (see Adiningsih, 2007).

The positive coefficient for the 'Time' variable in the two-truncation regression models suggests that Indonesian banks improved their efficiency profiles over time. However, the negative coefficient of the 'Time_sq' variable in all models implies that long-term banking efficiency is in decline. This result may be driven by the fact that the banks show greater focus towards obtaining quick profits rather than being profit-driven by stable long-term investments. Although our sample covers only 19 time periods, another possible explanation lies in the absence of a 'long memory' strategy among banks in their profit-generating policy. 


\subsection{Results of the Productivity Analysis}

Tables 8 and 9 provide a summary of the average and individual Malmquist productivity index and its components for the listed banks studied respectively. Interestingly, during the period analysed, the trend of the index is found to be primarily determined by technological changes (that is, frontier shifts). Between April and December 2006, however, the main driver of productivity was the changes in profit (that is, technical) efficiency (see Figure 1). This time span corresponds to the beginning of difficulties in the U.S. sub-prime market, hence suggesting that, anticipating the situation in the global market, Indonesian banks concentrated mainly on improving technical efficiency during this period. In general, the results show that, over the study's horizon, the sample banks displayed volatile productivity patterns in their profit-generating operations. Furthermore, in the period between December 2006 and January 2007, the steep decline in productivity can be traced to technological regression.

\section{INSERT TABLES 8 AND 9}

At the individual level (see Table 9), although some banks displayed somewhat steadier changes in their productivity (e.g., "ddhb", "ddpi”, "idqr”, “idsb”, "ihhr", "iiap", "iiar", "iihb", "iimb", "iisi”, "ipqa", "ipqb" and "irsb”), several banks experienced sharp productivity fluctuations. These banks are "iihi", "iihp", "iiir" and "iipi". However, the most extreme instability in productivity and its constituents is displayed by bank "idqa". Its monthly Malmquist productivity index ranged from a low of 0.06 to a high of 6.13. Although the deviation in technological change of this bank was considerable, the main source of "idqa's" volatile productivity stems from severe deviations in technical efficiency.

The unstable pattern of the productivity index, and the associated volatility in technical efficiency, thus raise associated questions and concerns about the profitgenerating activity of Indonesian banks. Given the recent distress in the sub-prime market, an important policy implication of our results is the possible need for a close 
scrutiny of the profit-generating technology of Indonesian banking to identify and eliminate investments bearing inappropriate risk profiles.

\section{SUMMARY AND CONCLUSIONS}

Combining the non-parametric models of Tone (2001 and 2002) with an adaptation of Simar and Wilson's (2007) bootstrapping methodology and adopting a profit-based approach, we have analysed the efficiency of Indonesian banks listed on the Jakarta Stock Exchange during most of the period 2006/07. To our knowledge, this represents the first published efficiency study focusing solely on Indonesian banks and certainly the first to use confidential monthly supervisory data collated by the central bank, Bank Indonesia.

Our findings support the idea of an efficient Indonesian stock market, with the market valuing banks in accordance with their performance. Moreover, we find a positive correlation between the JCI index of the Indonesian Stock Exchange and bank efficiency. Interestingly, we also find that, under the super-efficiency analysis, those banks with foreign stakeholders tend to perform less well than their purely domestic counterparts. Finally, our Malmquist analysis demonstrates that Indonesia's listed banks displayed volatile productivity patterns in their profit-generating operations during 2006/07. Although the trend of the index is found to be mainly driven by technological changes during this period, with technological regression causing the steep decline in productivity revealed between December 2006 and January 2007, changes in technical [profit-based] efficiency did act as the driver of productivity over the period April to December 2006.

The implications of this study for Indonesian policymakers are three-fold. Firstly, resources should be devoted to trying to understand the reasons for the marked differences recorded in individual banks' profit-based efficiency. The findings can then be shared with the industry with a view to raising overall levels of efficiency. Secondly, outliers, at both ends of the efficiency spectrum (as demonstrated by the recent nationalization of Northern Rock, previously one of the most efficient UK banks-see 
Hall, 2008), merit closer supervisory scrutiny. And thirdly, the results should be used to identify those banks which might usefully benefit from 'assisted mergers' as part of the continuing process of consolidation aimed at enhancing banking sector stability. 
Table 1.

The Structure of the Indonesian Banking Industry at end-June 2007.

\begin{tabular}{lcl}
\hline Type of Bank & Number of Banks & $\begin{array}{c}\text { Total Assets } \\
\text { (IDR tn.) }\end{array}$ \\
\hline $\begin{array}{l}\text { State-owned banks } \\
\text { Foreign exchange private national }\end{array}$ & 5 & 641.1 \\
banks & 35 & 691.2 \\
Non-foreign exchange private & 36 & 32.5 \\
national banks & & \\
Regional government-owned banks & 26 & 165.0 \\
Joint venture banks & 17 & 78.0 \\
Foreign banks (branching) & 11 & 163.0 \\
\hline Total & 130 & $1,770.8$ \\
\hline
\end{tabular}

Table 2.

Some Financial Indicators for the Indonesian Banking System at endJune 2007.

\begin{tabular}{lc}
\hline Total Assets (IDR tn.) & $1,770.8$ \\
\hline Deposits (IDR tn.) & $1,353.7$ \\
- current accounts & 371.2 \\
- savings accounts & 354.6 \\
- time deposits & 628.0 \\
\hline Productive assets (IDR tn.) & $1,641.44$ \\
- loans & 904.1 \\
- certificates of Bank Indonesia & 202.1 \\
- securities held and other claims & 342.0 \\
- interbank assets & 165.1 \\
- equity participation & 6.0 \\
\hline Net interest income (IDR tn.) & 7.7 \\
Capital adequacy ratio (risk-adjusted) (\%) & 20.7 \\
Gross non-performing loans ratio (\%) & 6.36 \\
Return on assets (\%) & 2.8 \\
Net interest margin (\%) & 0.47 \\
Operating expense to operating income ratio & 84.60 \\
Loans to deposits ratio & 66.8 \\
\hline
\end{tabular}

Source: Bank Indonesia 
Table 3. First stage estimation results: SBM efficiency and super-efficiency estimates

\begin{tabular}{|c|c|c|c|c|c|c|c|c|c|c|c|c|c|c|c|c|c|c|c|c|}
\hline ank & $p=01$ & vec & - & 5-04 & & & & & & & & & & & -03 & 7-04 & 7-05 & 7-06 & 7-07 & \\
\hline & 637 & 500 & & 427 & & 190 & 508 & & & & & & & & & 625 & & & & \\
\hline & & & & & & & & & & & & & & & & & & & & \\
\hline$q a^{*}$ & 346 & 290 & 588 & 0.882 & 112 & .418 & 0.516 & 0.574 & & & 0.672 & 0.698 & 415 & 0.564 & 0.559 & 3 & & 7 & & \\
\hline & 533 & 550 & 522 & 00 & $?$ & 661 & 996 & 00 & 710 & $0.7<$ & 76 & 9 & 2 & 08 & 27 & 72 & & 30 & & \\
\hline & .046) & 998 & 0.996 & .001) & 0.971 & 0.999 & .017) & 0.999 & 0.992 & 0.999 & 0.969 & 1) & & & 966 & 0.998 & 7 & $\begin{array}{l}.000 \\
.001)\end{array}$ & & \\
\hline & & 425 & 51 & 546 & 6 & 566 & 0750 & 5 & .830 & 086 & 893 & & & & 59 & & & & & \\
\hline$a n^{*}$ & 0.625 & 0.616 & 0.609 & 0.683 & 0.725 & 0.716 & 0.759 & 0.815 & 0.864 & 0.876 & 0.928 & & $\begin{array}{l}00 \\
94)\end{array}$ & 0952 & 0.999 & $\begin{array}{l}1.000 \\
1.026)\end{array}$ & $\begin{array}{c}1.000 \\
(1.061)\end{array}$ & 8 & & \\
\hline & 0.788 & 5 & .979 & 857 & .940 & 973 & 1. & & & 7 & $\begin{array}{l}0 \\
1 \text { 1) }\end{array}$ & & & & 79 & 787 & 0.829 & 53 & 70 & \\
\hline & 115 & 170 & 102 & 532 & & 579 & & & & 658 & & & & & & 526 & & & & \\
\hline & & & & & & & & & & & & & & & & & & & & \\
\hline & & & & & & & & & & & & & & & & & & & & \\
\hline & & $\begin{array}{r}1 \\
(1\end{array}$ & 0.963 & & & 0.997 & & & 0.992 & 003) & & & & & 0.885 & & & 0.989 & & \\
\hline & & & 639 & & 0.677 & .660 & 0.687 & 0.719 & & 0.942 & & & 760 & & & & & 0.992 & & \\
\hline & & 0.98 & 0.989 & 0.982 & & & 0.984 & & & 0.952 & & & & & & & & & & \\
\hline & & & 370 & 391 & & 415 & 426 & & 132 & 0.440 & & & & & & & & & & \\
\hline & & 0.556 & 0.599 & & 0.007 & 100 & & .001) & & 0.823 & 0.888 & 0.884 & 0.665 & & 0.674 & 0.702 & & 0.748 & & \\
\hline & & & 0.670 & 682 & & 0.647 & 0.658 & 0662 & 0.666 & 0.652 & 0.645 & & & & & 0.911 & 0.868 & & & \\
\hline & $\begin{array}{r}1 \\
(1\end{array}$ & & & 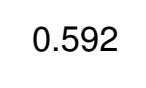 & & .010 & דוt. & & טל & 0.642 & 0.629 & 0 & 0.550 & $0<0$ & .495 & 0.494 & 1 & 0.484 & 06 & \\
\hline & & & & & & & 0.903 & & & & & & & & & & & & & \\
\hline & & & 0.000 & T. & & 0.050 & 0.051 & & $0.10<$ & 0.80 & 0.801 & & & & & .000 & & 0.001 & & \\
\hline$p q b$ & 0.822 & 0.670 & 709 & 0.671 & 0.838 & 671 & 0.671 & 725 & .75 & 0.77 & 0.764 & 0.754 & & 0.745 & 0.767 & 0.729 & 0.730 & 0.773 & 0.737 & \\
\hline & & & & & & & & & & & & & & & & & & & & \\
\hline & 02 & & & 661 & 0.685 & 694 & 0.710 & 1 & .757 & 0.772 & 69 & 3 & 36 & 65 & & .702 & & & & \\
\hline $\mathbf{s b}$ & 37 & 3 & 530 & 85 & 16 & 59 & 680 & 04 & 36 & 0.760 & 89 & 13 & 45 & 0.862 & & 995 & $\begin{array}{l}00 \\
08) \\
\end{array}$ & 00 & & \\
\hline
\end{tabular}

Notes: SBM super-efficiency scores are in brackets. * - partially foreign-owned bank. 


\section{Table 4}

\section{Results of the truncated regression with two truncations: SBM efficiency measures (Algorithm 1)}

\begin{tabular}{llllllll}
\hline & Est.Coef. & \multicolumn{5}{c}{ Bounds of the Bootstrap Est. Confidence Intervals } \\
& & $5 \%$ low & $5 \%$ up & $1 \%$ low & $1 \%$ up & $10 \%$ low & $10 \%$ up \\
\hline Constant & 0.1614 & -0.2379 & 0.5259 & -0.3450 & 0.6519 & -0.1677 & 0.4814 \\
Share price & $0.00003 *$ & 0.00002 & 0.00005 & 0.00002 & 0.000055 & 0.00003 & 0.00005 \\
F.O.S & -0.0073 & -0.0778 & 0.0689 & -0.1023 & 0.0904 & -0.0666 & 0.0559 \\
JCI index & $0.0003 * * *$ & -0.00001 & 0.0006 & -0.00010 & 0.00071 & 0.00005 & 0.00055 \\
Time & $0.0293 *$ & 0.0137 & 0.0437 & 0.0092 & 0.0477 & 0.0158 & 0.0414 \\
Time_sq & $-0.002 *$ & -0.0031 & -0.0009 & -0.0035 & -0.0006 & -0.0029 & -0.0011 \\
$\hat{\sigma}_{\varepsilon}$ & $0.1902 *$ & 0.1726 & 0.2071 & 0.1681 & 0.2146 & 0.1750 & 0.2040 \\
\hline
\end{tabular}

Notes: Statistical significance:* denotes statistically significant at the $1 \%$ level; ** denotes statistically significant at the $5 \%$ level; and $* * *$ denotes statistically significant at the $10 \%$ level (according to the bootstrap confidence intervals).

Table 5

Results of the truncated regression with two truncations: SBM efficiency measures (Algorithm 2)

\begin{tabular}{llllllll}
\hline & Est.Coef. & \multicolumn{7}{c}{ Bounds of the Bootstrap Est. Confidence Intervals } \\
& & $5 \%$ low & $5 \%$ up & $1 \%$ low & $1 \%$ up & $10 \%$ low & $10 \%$ up \\
\hline Constant & -0.3569 & -1.1151 & 0.3781 & -1.4273 & 0.5749 & -0.9637 & 0.2442 \\
Share price & $0.0001 *$ & 0.00005 & 0.00011 & 0.00004 & 0.00013 & 0.00005 & 0.00010 \\
F.O.S & -0.071 & -0.2083 & 0.0557 & -0.2311 & 0.0882 & -0.1805 & 0.0342 \\
JCI index & $0.0008 *$ & 0.00021 & 0.00139 & 0.00004 & 0.00171 & 0.00029 & 0.00130 \\
Time & $0.034 * *$ & 0.0066 & 0.0646 & -0.0021 & 0.0755 & 0.0102 & 0.0583 \\
Time_sq & $-0.0034 *$ & -0.0056 & -0.0014 & -0.0065 & -0.0008 & -0.0052 & -0.0016 \\
$\hat{\sigma}_{\varepsilon}$ & $0.2679 *$ & 0.2286 & 0.3099 & 0.2227 & 0.3397 & 0.2344 & 0.3045 \\
\hline
\end{tabular}

Notes: Statistical significance:* denotes statistically significant at the $1 \%$ level; $* *$ denotes statistically significant at the $5 \%$ level; and $* * *$ denotes statistically significant at the $10 \%$ level (according to the bootstrap confidence intervals). 
Table 6

Results of the truncated regression with one truncation: SBM super-efficiency measures (Algorithm 1)

\begin{tabular}{llllllll}
\hline & Est.Coef. & \multicolumn{5}{c}{ Bounds of the Bootstrap Est. Confidence Intervals } \\
& & $5 \%$ low & $5 \%$ up & $1 \%$ low & $1 \%$ up & $10 \%$ low & $10 \%$ up \\
\hline Constant & -0.1733 & -0.6640 & 0.3038 & -0.8136 & 0.4645 & -0.5838 & 0.2251 \\
Share price & $0.0001^{*}$ & 0.00004 & 0.00007 & 0.00004 & 0.00008 & 0.00004 & 0.00007 \\
F.O.S & $-0.070^{* * *}$ & -0.1624 & 0.0132 & -0.1903 & 0.0499 & -0.1480 & -0.0016 \\
JCI index & $0.0006^{*}$ & 0.0002 & 0.0010 & 0.0001 & 0.0011 & 0.0003 & 0.0009 \\
Time & 0.013 & -0.0064 & 0.0323 & -0.0128 & 0.0387 & -0.0026 & 0.0288 \\
Time_sq & $-0.0022^{*}$ & -0.0035 & -0.0009 & -0.0040 & -0.0005 & -0.0033 & -0.0012 \\
$\hat{\sigma}_{\varepsilon}$ & $0.2679^{*}$ & 0.2420 & 0.2784 & 0.2371 & 0.2833 & 0.2455 & 0.2757 \\
\hline
\end{tabular}

Notes: Statistical significance:* denotes statistically significant at the $1 \%$ level; ** denotes statistically significant at the 5\% level; and $* * *$ denotes statistically significant at the $10 \%$ level (according to the bootstrap confidence intervals).

Table 7

Results of the truncated regression with one truncation: SBM super-efficiency measures (Algorithm 2)

\begin{tabular}{llllllll}
\hline & Est.Coef. & \multicolumn{5}{c}{ Bounds of the Bootstrap Est. Confidence Intervals } \\
& & $5 \%$ low & $5 \%$ up & $1 \%$ low & $1 \%$ up & $10 \%$ low & $10 \%$ up \\
\hline Constant & -0.0164 & -0.5123 & 0.3960 & -0.6606 & 0.5845 & -0.4293 & 0.3189 \\
Share price & $0.000029^{*}$ & 0.00002 & 0.00005 & 0.00001 & 0.00005 & 0.00002 & 0.00004 \\
F.O.S & $-0.1524^{*}$ & -0.2465 & -0.0875 & -0.2737 & -0.0599 & -0.2343 & -0.0983 \\
JCI index & $0.0004^{* *}$ & 0.00011 & 0.00082 & -0.00002 & 0.00095 & 0.00017 & 0.00076 \\
Time & 0.0018 & -0.0164 & 0.0206 & -0.0216 & 0.0269 & -0.0130 & 0.0177 \\
Time_sq & $-0.0013^{* *}$ & -0.0027 & -0.0001 & -0.0030 & 0.0003 & -0.0024 & -0.0003 \\
$\hat{\sigma}_{\varepsilon}$ & $0.2660^{*}$ & 0.2288 & 0.2659 & 0.2245 & 0.2707 & 0.2315 & 0.2618 \\
\hline
\end{tabular}

Notes: Statistical significance:* denotes statistically significant at the $1 \%$ level; ** denotes statistically significant at the 5\% level; and $* * *$ denotes statistically significant at the $10 \%$ level (according to the bootstrap confidence intervals). 
Table 8.

Average slacks-based Malmquist productivity index and its components

for listed Indonesian banks during the period Jan. 2006 to July 2007

\begin{tabular}{llllllllll}
\hline & $06-01 /$ & $06-02 /$ & $06-03 /$ & $06-04 /$ & $06-05 /$ & $06-06 /$ & $06-07 /$ & $06-08 /$ & $06-09 /$ \\
& $06-02$ & $06-03$ & $06-04$ & $06-05$ & $06-06$ & $06-07$ & $06-08$ & $06-09$ & $06-10$ \\
\hline MI & 1.163 & 1.144 & 1.285 & 1.005 & 1.188 & 1.144 & 1.055 & 1.237 & 1.040 \\
TEC & 1.036 & 1.501 & 1.092 & 0.976 & 1.152 & 1.070 & 1.009 & 1.232 & 0.982 \\
FS & 1.133 & 1.038 & 1.311 & 1.035 & 1.043 & 1.102 & 1.051 & 1.032 & 1.069 \\
\hline & & & & & & & & & \\
\hline & $06-10 /$ & $06-11 /$ & $06-12 /$ & $07-01 /$ & $07-02 /$ & $07-03 /$ & $07-04 /$ & $07-05 /$ & $07-06 /$ \\
& $06-11$ & $06-12$ & $07-01$ & $07-02$ & $07-03$ & $07-04$ & $07-05$ & $07-06$ & $07-07$ \\
\hline MI & 1.069 & 1.100 & 0.834 & 1.177 & 1.170 & 1.072 & 1.249 & 1.184 & 1.087 \\
TEC & 0.996 & 1.076 & 1.175 & 1.072 & 1.020 & 0.990 & 1.067 & 1.041 & 0.990 \\
FS & 1.066 & 1.019 & 0.791 & 1.143 & 1.190 & 1.092 & 1.165 & 1.124 & 1.126 \\
\hline
\end{tabular}

Notes: MI - Malmquist Index; FS - Frontier Shift (technological change); TEC - Technical Efficiency Change. 
Table 9.

Results of the Malmquist productivity index and its components for individual listed

Indonesian banks

\begin{tabular}{lrrrrrrrrr}
\hline Bank & \multicolumn{3}{c}{ MI } & \multicolumn{3}{c}{ TEC } & & & FS \\
ddhb & 0.998 & 0.622 & 1.693 & 1.011 & 0.901 & 1.114 & 0.991 & 0.690 & 1.776 \\
ddpi & 1.045 & 0.807 & 1.297 & 1.063 & 0.714 & 1.463 & 0.998 & 0.800 & 1.464 \\
idqa & 1.629 & 0.063 & 6.133 & 2.017 & 0.109 & 11.261 & 1.175 & 0.266 & 3.980 \\
idqr & 1.061 & 0.607 & 1.316 & 1.031 & 0.794 & 1.319 & 1.026 & 0.765 & 1.201 \\
idsb & 1.036 & 0.979 & 1.150 & 1.007 & 0.862 & 1.119 & 1.031 & 0.986 & 1.161 \\
ihhr & 1.042 & 0.805 & 1.414 & 1.047 & 0.858 & 1.360 & 0.994 & 0.925 & 1.058 \\
iiap & 1.023 & 0.857 & 1.229 & 1.013 & 0.787 & 1.614 & 1.021 & 0.761 & 1.217 \\
iiar & 0.996 & 0.692 & 1.155 & 0.998 & 0.838 & 1.271 & 1.000 & 0.734 & 1.089 \\
iibi & 1.102 & 0.375 & 1.474 & 1.022 & 0.976 & 1.148 & 1.076 & 0.384 & 1.390 \\
iihb & 1.083 & 0.425 & 1.442 & 0.994 & 0.891 & 1.124 & 1.086 & 0.477 & 1.413 \\
iihi & 1.133 & 0.212 & 3.775 & 1.045 & 0.370 & 2.246 & 1.037 & 0.479 & 1.681 \\
iihp & 1.466 & 0.832 & 2.246 & 1.068 & 0.505 & 2.179 & 1.503 & 0.382 & 2.402 \\
liir & 1.658 & 0.199 & 4.502 & 1.263 & 0.165 & 3.826 & 1.387 & 0.883 & 2.310 \\
iimb & 0.949 & 0.743 & 1.363 & 0.995 & 0.866 & 1.065 & 0.953 & 0.825 & 1.357 \\
iimr & 1.028 & 0.389 & 1.247 & 1.000 & 0.836 & 1.072 & 1.022 & 0.465 & 1.164 \\
iipb & 1.125 & 0.628 & 1.611 & 1.195 & 0.359 & 3.246 & 1.197 & 0.472 & 3.158 \\
iipi & 1.375 & 0.566 & 2.259 & 1.118 & 0.376 & 3.204 & 1.377 & 0.382 & 1.965 \\
iipp & 0.966 & 0.517 & 1.308 & 0.978 & 0.389 & 1.274 & 1.002 & 0.631 & 1.329 \\
iisi & 1.033 & 0.951 & 1.203 & 1.007 & 0.943 & 1.202 & 1.027 & 0.791 & 1.142 \\
ipqa & 1.056 & 0.704 & 1.219 & 1.020 & 0.694 & 1.274 & 1.037 & 0.888 & 1.166 \\
ipqb & 0.922 & 0.710 & 1.293 & 1.027 & 0.868 & 1.168 & 0.901 & 0.723 & 1.302 \\
iqma & 1.073 & 0.630 & 1.755 & 1.004 & 0.566 & 1.655 & 1.095 & 0.467 & 1.339 \\
irrb & 1.030 & 0.480 & 1.562 & 0.985 & 0.858 & 1.349 & 1.047 & 0.466 & 1.168 \\
irsb & 1.107 & 0.686 & 1.712 & 1.061 & 0.919 & 1.605 & 1.059 & 0.428 & 1.366 \\
\hline
\end{tabular}

Notes: MI - Malmquist Index; FS - Frontier Shift (technological change); TEC - Technical Efficiency Change. 
Figure 1.

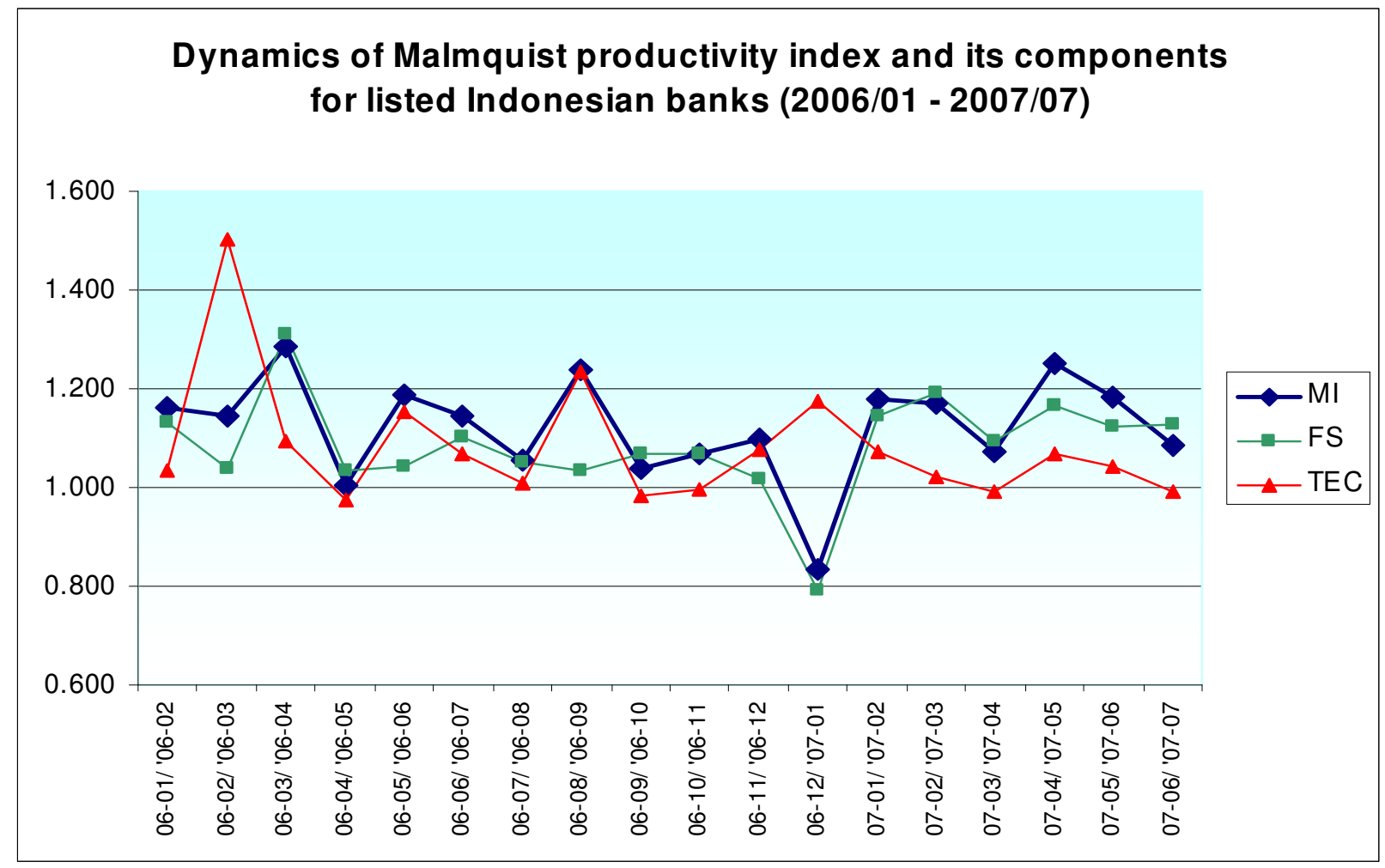

Notes: MI - Malmquist Index; FS - Frontier Shift (technological change); TEC - Technical Efficiency Change. 


\section{Appendix.}

Table A1.

Estimation results from the first part of the bootstrapping procedure of Algorithm 2: SBM efficiency estimates

\begin{tabular}{lrrrrrrrrr}
\hline \multicolumn{1}{c}{ Bank } & \multicolumn{3}{c}{ SBM efficiency } & \multicolumn{3}{c}{ Estimated bias } & \multicolumn{3}{c}{ Bias-corr. SBM efficiency } \\
& average & min & $\max$ & average & min & max & average & min & max \\
ddhb & 0.563 & 0.415 & 0.688 & 0.038 & -0.054 & 0.175 & 0.601 & 0.478 & 0.793 \\
ddpi & 0.498 & 0.313 & 0.710 & 0.028 & -0.207 & 0.175 & 0.526 & 0.377 & 0.694 \\
idqa & 0.641 & 0.112 & 1.000 & 0.051 & -0.005 & 0.161 & 0.691 & 0.121 & 0.999 \\
idqr & 0.702 & 0.522 & 0.919 & 0.059 & 0.034 & 0.080 & 0.760 & 0.567 & 0.994 \\
idsb & 0.993 & 0.966 & 1.000 & 0.003 & -0.006 & 0.031 & 0.996 & 0.985 & 1.000 \\
ihhr & 0.728 & 0.425 & 0.893 & 0.080 & -0.042 & 0.136 & 0.808 & 0.533 & 0.979 \\
iiap & 0.849 & 0.609 & 1.000 & 0.063 & -0.001 & 0.270 & 0.911 & 0.711 & 1.000 \\
iiar & 0.891 & 0.723 & 1.000 & 0.020 & -0.039 & 0.125 & 0.911 & 0.685 & 1.000 \\
iibi & 0.566 & 0.444 & 0.704 & 0.028 & -0.009 & 0.061 & 0.594 & 0.436 & 0.764 \\
iihb & 0.506 & 0.394 & 0.651 & 0.018 & -0.016 & 0.049 & 0.525 & 0.378 & 0.700 \\
iihi & 0.561 & 0.347 & 0.779 & 0.007 & -0.032 & 0.055 & 0.568 & 0.328 & 0.833 \\
iihp & 0.984 & 0.885 & 1.000 & -0.069 & -0.208 & 0.008 & 0.914 & 0.738 & 1.000 \\
liir & 0.899 & 0.639 & 1.000 & 0.017 & -0.029 & 0.134 & 0.916 & 0.609 & 1.000 \\
iimb & 0.982 & 0.877 & 1.000 & 0.014 & -0.005 & 0.098 & 0.997 & 0.974 & 1.000 \\
iimr & 0.370 & 0.279 & 0.442 & 0.012 & 0.005 & 0.021 & 0.382 & 0.295 & 0.462 \\
iipb & 0.736 & 0.480 & 1.000 & 0.009 & -0.100 & 0.052 & 0.745 & 0.474 & 0.936 \\
iipi & 0.792 & 0.645 & 1.000 & -0.045 & -0.198 & 0.074 & 0.746 & 0.562 & 1.000 \\
iipp & 0.595 & 0.484 & 1.000 & -0.010 & -0.063 & 0.043 & 0.585 & 0.456 & 1.000 \\
iisi & 0.868 & 0.681 & 1.000 & 0.030 & -0.021 & 0.091 & 0.899 & 0.660 & 1.000 \\
ipqa & 0.671 & 0.512 & 0.841 & 0.055 & 0.027 & 0.111 & 0.726 & 0.623 & 0.894 \\
ipqb & 0.753 & 0.670 & 1.000 & 0.085 & -0.064 & 0.176 & 0.838 & 0.748 & 0.999 \\
iqma & 0.651 & 0.491 & 0.855 & 0.034 & -0.007 & 0.097 & 0.686 & 0.512 & 0.952 \\
irrb & 0.724 & 0.586 & 0.902 & 0.009 & -0.142 & 0.057 & 0.733 & 0.568 & 0.839 \\
irsb & 0.750 & 0.337 & 1.000 & 0.008 & -0.050 & 0.052 & 0.758 & 0.354 & 1.000 \\
\hline
\end{tabular}


Table A2.

Estimation results from the first part of the bootstrapping procedure of Algorithm 2: SBM super-efficiency estimates

\begin{tabular}{|c|c|c|c|c|c|c|c|c|c|}
\hline \multirow[t]{2}{*}{ Bank } & \multicolumn{3}{|c|}{ SBM super-efficiency } & \multicolumn{3}{|c|}{ Estimated bias } & \multicolumn{3}{|c|}{$\begin{array}{c}\text { Bias-corr. SBM super- } \\
\text { efficiency }\end{array}$} \\
\hline & average & $\min$ & $\max$ & average & $\min$ & $\max$ & average & $\min$ & $\max$ \\
\hline ddhb & 0.563 & 0.415 & 0.688 & -0.088 & -0.164 & 0.135 & 0.475 & 0.364 & 0.772 \\
\hline ddpi & 0.498 & 0.313 & 0.710 & -0.071 & -0.148 & 0.124 & 0.427 & 0.319 & 0.586 \\
\hline idqa & 0.657 & 0.112 & 1.255 & -0.077 & -0.274 & 0.117 & 0.580 & 0.099 & 1.281 \\
\hline idqr & 0.702 & 0.522 & 0.919 & -0.154 & -0.218 & -0.061 & 0.548 & 0.417 & 0.700 \\
\hline idsb & 1.012 & 0.966 & 1.116 & -0.073 & -0.167 & 0.010 & 0.939 & 0.833 & 1.070 \\
\hline ihhr & 0.728 & 0.425 & 0.893 & -0.102 & -0.165 & 0.052 & 0.626 & 0.411 & 0.762 \\
\hline iiap & 0.877 & 0.609 & 1.294 & -0.132 & -0.367 & 0.172 & 0.745 & 0.475 & 1.293 \\
\hline iiar & 0.892 & 0.723 & 1.015 & -0.295 & -0.350 & -0.246 & 0.598 & 0.469 & 0.683 \\
\hline iibi & 0.566 & 0.444 & 0.704 & -0.144 & -0.153 & -0.1 & 0.422 & 0.307 & 0.555 \\
\hline iihb & 0.506 & 0.394 & 0.651 & -0.133 & -0.141 & -0.119 & 0.373 & 0.266 & 0.513 \\
\hline iihi & 0.561 & 0.347 & 0.779 & -0.169 & -0.215 & -0.106 & 0.392 & 0.222 & 0.572 \\
\hline iihp & 1.053 & 0.885 & 2.224 & -0.312 & -0.527 & 0.066 & 0.741 & 0.485 & 2.237 \\
\hline liir & 1.023 & 0.639 & 2.909 & -0.125 & -0.421 & 0.529 & 0.898 & 0.427 & 3.438 \\
\hline iimb & 1.025 & 0.877 & 1.356 & -0.132 & -0.258 & 0.106 & 0.894 & 0.736 & 1.461 \\
\hline iimr & 0.370 & 0.279 & 0.442 & -0.097 & -0.114 & -0.060 & 0.273 & 0.210 & 0.334 \\
\hline iipb & 0.736 & 0.480 & 1.000 & -0.221 & -0.385 & -0.130 & 0.515 & 0.350 & 0.663 \\
\hline iipi & 0.803 & 0.645 & 1.123 & -0.250 & -0.477 & 0.250 & 0.552 & 0.395 & 1.250 \\
\hline iipp & 0.610 & 0.484 & 1.274 & -0.167 & -0.219 & 0.045 & 0.442 & 0.313 & 1.319 \\
\hline iisi & 0.873 & 0.681 & 1.043 & -0.244 & -0.329 & -0.206 & 0.629 & 0.464 & 0.765 \\
\hline ipqa & 0.671 & 0.512 & 0.841 & -0.135 & -0.208 & -0.009 & 0.536 & 0.481 & 0.634 \\
\hline ipqb & 0.755 & 0.670 & 1.043 & -0.060 & -0.143 & 0.222 & 0.695 & 0.573 & 1.125 \\
\hline iqma & 0.651 & 0.491 & 0.855 & -0.155 & -0.210 & -0.127 & 0.496 & 0.364 & 0.645 \\
\hline irrb & 0.724 & 0.586 & 0.902 & -0.210 & -0.389 & -0.177 & 0.513 & 0.395 & 0.605 \\
\hline irsb & 0.751 & 0.337 & 1.009 & -0.216 & -0.378 & -0.077 & 0.535 & 0.261 & 0.719 \\
\hline
\end{tabular}




\section{REFERENCES:}

Adiningsih, S. (2007), "Indonesia: Ten Years After the Economic Crisis," Institute of Development Studies Bulletin, 38, 45-58.

Akhigbe, A. and McNulty, J.E. (2003), "The Profit Efficiency of Small US Commercial Banks," Journal of Banking and Finance, 27, 307-325.

Altunbas, Y., Liu, M-H., Molyneux, P. and Seth, R. (2000), "Efficiency and Risk in Japanese Banking," Journal of Banking and Finance, 24, 1605-1628.

Banker, R.D., Charnes, A. and Cooper, W.W. (1984), "Some Models for the Estimation of Technical and Scale Inefficiencies in Data Envelopment Analysis," Management Science, 30, 1078-1092.

Beccalli, E., Casu, B. and Girardone, C. (2006), "Efficiency and Stock Performance in European Banking", Journal of Business Finance and Accounting, 33 (1), 245262.

Benston, G.J. (1965), "Branch Banking and Economies of Scale," The Journal of Finance, 20, 312-331.

Berger, A.N. and Mester, L.J. (1997), "Inside the Black Box: What Explains Differences in the Efficiencies of Financial Institutions", Journal of Banking and Finance, 21 (7), $895-947$.

Bonin, J.P., Hasan, I. and Wachtel, P. (2005), "Bank Performance, Efficiency and Ownership in Transition Countries", Journal of Banking and Finance, 29 (1), 3153.

Caves, D.W., Christensen, L.R. and Diewert, W.E. (1982), "The Economic Theory of Index Numbers and the Measurement of Input, Output, and Productivity", Econometrica, 50 (6), 1393-1414.

Charnes, A., Cooper, W. and Rhodes, E. (1978), "Measuring the Efficiency of DecisionMaking Units," European Journal of Operational Research, 2, 429-444.

Chu, S.F. and Lim, G.H. (1998), "Share performance and profit efficiency of banks in an oligopolistic market: evidence from Singapore," Journal of Multinational Financial Management, 8, 55-168. 
Dogan, E. and Fausten, D.K. (2003), "Productivity and Technical Change in Malaysian Banking: 1989-1998," Asia-Pacific Financial Markets, 10, 205-237.

Drake, L. and Hall, M. J. B. (2003), "Efficiency in Japanese Banking: An Empirical Analysis," Journal of Banking and Finance, 27 (5), 891-917.

Drake, L., Hall, M.J.B. and Simper, R. (2006), “The Impact of Macroeconomic and Regulatory Factors on Bank Efficiency: A Non-Parametric Analysis of Hong Kong's Banking System," Journal of Banking and Finance, 30 (5), 1443-1466.

Drake, L., Hall, M.J.B. and Simper, R. (2008), "Bank Modelling Methodologies: A Comparative Non-Parametric Analysis of Efficiency in the Japanese Banking Sector" forthcoming, Journal of International Financial Markets, Institutions \& Money, (forthcoming).

Fan. L. and Shaffer, S. (2004), "Efficiency Versus Risk in Large Domestic US Banks," Managerial Finance, 30, 1-19.

Fare, R., Grosskopf, S. and Lovell, C.A.K. (1985), The Measurement of Efficiency of Production. Kluwer- Nijhoff Publishing, Boston.

Färe, R., Grosskopf, S., Lindgren, B. and Roos, P. (1992), "Productivity Change in Swedish Pharmacies 1980-1989: A Non-Parametric Malmquist Approach", Journal of Productivity Analysis, 3, 85-102.

Farrell, M.J. (1957), “The Measurement of Productive Efficiency," Journal of the Royal Statistical Society, Ser. A, 120, 253-281.

Fried, H.O., Schmidt, S.S. and Yaisawarng, S. (1999), "Incorporating the Operating Environment into a Nonparametric Measure of Technical Efficiency," Journal of Productivity Analysis, 12, 249-267.

Fries, S. and Taci, A. (2005), "Cost Efficiency of Banks in Transition: Evidence from 289 Banks in 15 Post-Communist Countries", Journal of Banking and Finance, 29 (1), 55-81.

Fukuyama, H., Guerra, R. and Weber, W.L. (1999), "Efficiency and Ownership: Evidence from Japanese Credit Cooperatives", Journal of Economics and Business, 51 (6), 473-487.

Gilbert, R.A. and Wilson, P.W. (1998), "Effects of Deregulation on the Productivity of Korean Banks," Journal of Economics and Business, 50, 133-155. 
Hall, M. J. B. (2008), “The Sub-prime Crisis, the Credit Squeeze and Northern Rock: The Lessons to Be Learned", Journal of Financial Regulation and Compliance, 16 (1), 19-34.

Havrylchyk, O. (2006), "Efficiency of the Polish banking industry: Foreign versus domestic banks", Journal of Banking and Finance, 30 (7), 1975-1996.

Hasan, I. and Marton, K. (2003), "Development and Efficiency of the Banking Sector in a Transitional Economy: Hungarian Experience", Journal of Banking and Finance, 27 (12), 2249-2271.

Hill, H. and Shirishi, T. (2007), "Indonesia After the Asian Crisis," Asian Economic Policy Review, 2, 123-141.

Jao, Y.C. (2001), The Asian Financial Crisis and the Ordeal of Hong Kong, Quorum Books, Greenwood Publishing.

Kenjegalieva, K., Simper, R., Weyman-Jones, T. G., and Zelenyuk, V., (2007), "Comparative Analysis of Banking Production Frameworks in Eastern European Financial Markets," Department of Economics Discussion Paper, Loughborough University, UK.

Kwan, S. H. (2002), "The X-Efficiency of Commercial Banks in Hong Kong," HKIMR Working Paper No. 12/2002.

Laeven, L. and Majnoni, G. (2003), "Loan Loss Provisioning and Economic Slowdowns:

Too Much, Too Late?" Journal of Financial Intermediation, 12, 178-197.

Leightner, J.E. and Knox-Lovell, C.A. (1998), "The Impact of Financial Liberalization on the Performance of Thai Banks," Journal of Economics and Business, 50, 115131.

Lensink, R., Meesters, A. and Naaborg, I. (2008), "Bank Efficiency and Foreign Ownership: Do Good Institutions Matter?", Journal of Banking and Finance, 32 (5), 834-844.

Liu, F.F. and Wang, P. (2008), "DEA Malmquist Productivity Measure: Taiwanese Semiconductor Companies", International Journal of Production Economics, $112,367-379$. 
McKillop, D.G., Glass, J.C. and Morikawa, Y. (1996), "The Composite Cost Function and Efficiency in Giant Japanese Banks," Journal of Banking \& Finance, 20 (10), $1651-1671$

Murray, J.D. and White, R.W. (1983), "Economies of Scale and Economies of Scope in Multiproduct Financial Institutions: A Study of British Columbia Credit Unions," The Journal of Finance, 38, 887-901.

Pulley, L.B. and Braunstein, Y.B. (1992), "A Composite Cost Function for Multiproduct Firms With an Application to Economies of Scope in Banking," Review of Economics and Statistics, 74, 214-230.

Sathye, M. (2003), "Efficiency of Banks in a Developing Economy: The Case of India," European Journal of Operational Research, 148 (3), 662-671.

Simar, L. and Wilson, P.W. (2007), "Estimation and Inference in Two-Stage, SemiParametric Models of Production Processes," Journal of Econometrics, 136 (1), 31-64.

Sturm, J.E. and Williams, B. (2004), "Foreign Bank Entry, Deregulation and Bank Efficiency: Lessons from the Australian Experience," Journal of Banking and Finance, 28 (7), 1775-1799.

Tone, K. (2001), "A Slacks-Based Measure of Efficiency in Data Envelopment Analysis," European Journal of Operational Research, 130, 498-509.

Tone, K. (2002), "A Slacks-Based Measure of Super-Efficiency in Data Envelopment Analysis," European Journal of Operational Research, 143, 32-41.

Unite, A.A. and Sullivan, M.J. (2003), "The Effect of Foreign Entry and Ownership Structure on the Philippine Domestic Banking Market," Journal of Banking and Finance, 27 (12), 2323-2345.

Williams, J. and Nguyen, N. (2005), "Financial Liberalisation, Crisis, and Restructuring: A Comparative Study of Bank Performance and Bank Governance in South East Asia," Journal of Banking and Finance, 29 (8/9), 2119-2154. 